\title{
Evaluation of Microbes through Microfiltration within the Water Treatment Processes
}

\author{
Moon Jung Shim¹, Jae Won $\operatorname{Lim}^{2}$, Tae Ue Kim² \\ ${ }^{1}$ Department of Clinical Laboratory Science, Ansan University, Ansan 15328, Korea \\ ${ }^{2}$ Department of Biomedical Laboratory Science, College of Health Sciences, Yonsei University, Wonju 26493, Korea
}

\section{정밀여과막 및 입상활성탄을 이용한 수처리 공정에 따른 박테리아 거동 평가}

심문정 ${ }^{1}$, 임재원 ${ }^{2}$, 김태우 $^{2}$

${ }^{1}$ 안산대학교 임상병리과, ${ }^{2}$ 연세대학교 보건과학대학 임상병리학과

\begin{abstract}
Economic growth has increased the living standards around the world. Water pollution, in particular, is a public relations issue because it poses a direct threat to everyone's lives. As of recently, the production of taste and odor (T\&O) compounds has been a common problem in the water industry. The adsorption process using granular activated carbon (GAC) has been the most widely used process. The objectives of this study were to evaluate the microorganisms before and after the backwashing of GAC and to identify the species of the microorganisms found. Five dominants microorganisms were confirmed after the microfiltration process from backwashing of GAC, and the dominant bacterial species were found to be $\beta$-proteobacterium species, Porphyrobacter donghaensis, Polaromonas rhizophaerae, Hydrogenophaga species, and Pseudonocardia species. However, when UV treatment after microfiltration was performed, Hydrogenophaga species and Psedonocardia species were eliminated. Herein, I conclude that the UV treatment post microfiltration process is more efficient than microfiltration process alone. The findings of this study may provide useful information regarding the management of microfiltration process.
\end{abstract}

Key words: Microfiltration, Granular activated carbon, Drinking water, Microorganism, 16S ribosomal RNA gene

\footnotetext{
This is an Open Access article distributed under the terms of the Creative Commons Attribution Non-Commercial License (http://creativecommons.org/licenses/by-nc/4.0) which permits unrestricted non-commercial use, distribution, and reproduction in any medium, provided the original work is properly cited.
}

Copyright () 2016 The Korean Society for Clinical Laboratory Science. All rights reserved.
Corresponding author: TaeUe Kim

Department of Biomedical Laboratory Science, College of Health Sciences, Yonsei University, 1 Yonseidae-gil, Wonju 26493, Korea

Tel: 82-33-760-2424

Fax: 82-33-760-2562

E-mail: kimtu@yonsei.ac.kr

Received: August 3, 2016

Revised ${ }^{\text {st. }}$ : August 29, 2016

Revised $2^{\text {nd. }}$ : August 30, 2016

Accepted: August 30, 2016

\section{서 론}

인구증가, 생활수준향상 및 공업발달 등의 다양한 요인으로 물 의 소비량이 증가하고 이에 따라 오 - 폐수의 발생량도 증가하여 상 수원의 수질이 악화되고 있는 실정이다. 그래서 먹는 물 및 지하수 의 수질관리를 위해 정부는 필요한 시책을 마련하여 수질기준을 설 정한 후 국민에게 양질의 수돗물이 공급되게 함으로써, 국민의 건
강에 이바지하는데 노력을 기울이고 있다[1,2]. 그럼에도 불구하고 최근 수질기준 항목에 해당하는 심미적 영양물질인 맛 - 냄새 유발 물질(taste \& odor, T\&O)에 대한 민원이 발생하여 먹는 물에 대한 신뢰성이 떨어지고 있다[3,4]. 1989년 수돗물의 중금속 사건, 1990년 트리할로메탄(trihalomethanes, THMs) 사건, 1991년 낙 동강 페놀오염사건, 1994년 낙동강 하류 정수장 악취사건 등 각종 수질오염 사고가 빈발하여 수돗물에 대한 국민의 신뢰가 낮아지고, 
양질의 수돗물에 대한 관심이 증폭되고 있는 실정이다. 국제적으로 도 병원성 미생물에 의한 수질오염사고로 인해 각 국가마다 정수처 리기준이 강화되고 먹는 물 수질기준이 강화되었다. 기존의 재래식 정수처리 공정은 부유물질 제거와 소독이 주 목적이었으나, 상수원 의 수질악화, 빈번한 유해물질 출현 및 사용자의 수질에 대한 기대 가 증가함에 따라 기존의 정수처리 방식으로는 높은 수질을 보장할 수 없게 되었다.

기존의 정수처리 공정은 병원성 박테리아 및 수인성 장 - 관계 바이러스를 제거하는데 어려움이 많아서 최근 입자성 물질 및 병원 성 미생물의 효과적인 처리를 위하여 모래여과 공정을 대체하기 위 한 방법으로 정밀막여과(microfiltration) 공정이 새로운 정수처리 공정으로 주목 받고 있다. 정수 처리에 있어서 정밀막여과 기술은 운전의 자동화, 유지관리의 용이성, 설치공간 및 에너지의 효율성, 안정된 처리수질 등을 장점으로, 소규모 시설을 비롯하여 노화에 따른 시설의 교체 및 신규설비에 급속도로 보급되고 있는 실정이 다. 문제가 되고 있는 병원성 박테리아와 바이러스 등을 거의 완벽 하게 제거 할 수 있는 것으로 보고되고 있고, 정밀여과막에 의한 바 이러스 제거율은 막의 특성에 따라 35 $99 \%$ 의 범위에 이른다고 한 다[5,6].

고도정수처리공정(advanced water treatment process)에서 입상활성탄(granular activated carbon, $\mathrm{GAC}$ ) 공정은 수돗물의 맛 - 냄새, TOC (total organic carbon) 및 DOC (dissolved organic carbon)의 제거 등에 큰 효과를 가져온다. 또한 입상활성 탄을 장기간 가동 시 활성탄 내 세공(pore)에 수계 내 박테리아가 부착 및 서식하며 생물막(biofilm)을 형성하게 되는데 이것을 생물 활성탄(biological activated carbon, $\mathrm{BAC}$ )이라 한다. 생물활성탄 내 생물막은 생물학적 분해능(biological degradation activity)을 가지면서 다양한 유기물질의 흡착 및 분해를 도와 원수 내 유기오 염 물질을 효과적으로 제거한다[7]. 이러한 생물활성탄은 맛 - 냄 새 유발물질과 더불어 천연유기물질(natural organic matter)와 같은 유기물질 제거에 효과적이기 때문에 이를 적용한 연구결과가 보고되고 있다[8-11]. 그러나 활성탄 공정은 수중의 용존 유기물질 제거의 효과적이지만 몇 가지 한계를 지니고 있다. 고도정수처리공 정에서 입상활성탄을 이용한 공정은 사용 초기에는 수중의 오염물 질에 대한 높은 제거율을 나타내지만 사용기간이 경과할수록 한계 를 지니게 된다. 가장 큰 문제는 활성탄 세공 내 흡착력을 가지는 흡 착점(adsorption site)이 수계 내 박테리아나 다른 입자성 물질과 결합하여 흡착력을 소실하면서 흡착능이 저하가 일어나게 된다는 점이다[12,13]. 이러한 흡착능 저하를 극복하기 위해 역세척 (back-washing)을 하게 된다. 그러나 역세척을 시행하게 되면 일 시적으로 탁도와 $\mathrm{TOC}, \mathrm{DOC}$ 등이 증가하게 되고 이로 인해 역세척
후 발생되는 생산수에는 일시적으로 박테리아를 포함하는 고농도 의 오염물질이 유입 될 가능성이 높다[14,15].

우리나라의 경우 2006년 6월 수도법이 개정되어 $5,000 \mathrm{~m}^{3} /$ day 이하의 막 여과시설이 정수처리기술로 인정하였고, 2004년부터 환경부의 Eco-star project 국가사업으로 중대형 정수장에 대한 막 여과기술이 추진되었다. 또한, 맛 - 냄새 유발물질에 대한 방안 으로 국내, 외 여러 정수장에서 고도정수처리 공정으로 생물활성탄 (biological activated carbon, $\mathrm{BAC}$ )이 사용되고 있다. 그러나, 정 밀막여과 공정과 입상활성탄 공정의 연계 과정에서 발생되는 박테 리아의 탈리와 역세척 과정의 영향에 대한 평가는 미비한 실정이다.

따라서, 본 연구에서는 정밀막여과 공정 및 입상활성탄 공정이 적용된 $G$ 정수장 내의 모형플랜트를 대상으로 물 시료 및 입상활성 탄 시료를 채취하여 실험을 진행하였다. 먼저 정밀막여과 공정과 입상활성탄 공정 연계 시 유입수 및 처리수에서 박테리아의 거동이 어떻게 변화하는지 확인을 하였다. 그리고 박테리아 증식으로 생물 활성탄화 된 입상활성탄 공정에서 탈리되어 나오는 박테리아의 기 존량과 입상활성탄 역세척 과정에서 탈리되어 나타나는 박테리아 의 량을 비교분석하기 위한 실험을 진행하였다. 또한 이때 탈리되 어 나오는 박테리아의 종을 분석하여 우점종으로 자리잡은 박테리 아 종 분석을 실시하였다. 본 연구를 바탕으로 정밀막여과 공정 및 입상활성탄 공정이 적용된 수질 맞춤형 고도정수처리 공정개발에 기초적인 자료를 제공하고자 한다.

\section{재료 및 방법}

\section{1. 고도정수처리 설비 운전 시스템 정보}

본 실험에서는 $\mathrm{G}$ 정수장 내 설치된 파일롯 형태(pilot-scale)의 고도정수처리 설비를 이용하였고 그 구성을 살펴보면 공정 전단에 입자성 물질 제거를 위한 정밀막여과 공정이 있으며 후단에 유기물 질 제거를 위한 입상활성탄 공정이 있다. 활성탄 공정의 접촉시간 은 평균 14 분이다(Fig. 1, Table 1). 본 실험에서 사용한 입상활성 탄 시료는 N사의 Norit $1240 \mathrm{GAC}$ 로 고도정수처리 설비를 6개월 이상 가동하여 생물활성탄화 한 뒤, 활성탄 접촉조의 표층부 30 $50 \mathrm{~cm}$ 아래에서 채취하여 사용하였다. 입상활성탄의 물리적 특성 을 살펴보면 활성탄 내 세공은 주로 미세세공(micro-pore)으로 구 성되어 있다(Table 2). 본 공정에 적용된 원수는 $G$ 정수장 에 유입되 는 낙동강 수계 유입수를 사용하였다(Table 3).

\section{2. 박테리아 배양 및 수 측정}

본 실험에서는 정밀여과막 공정 및 입상활성탄 공정의 유입수 및 처리수를 시료로 사용하였다. 각 물 시료를 $250 \mathrm{~mL}$ 채취한 후 


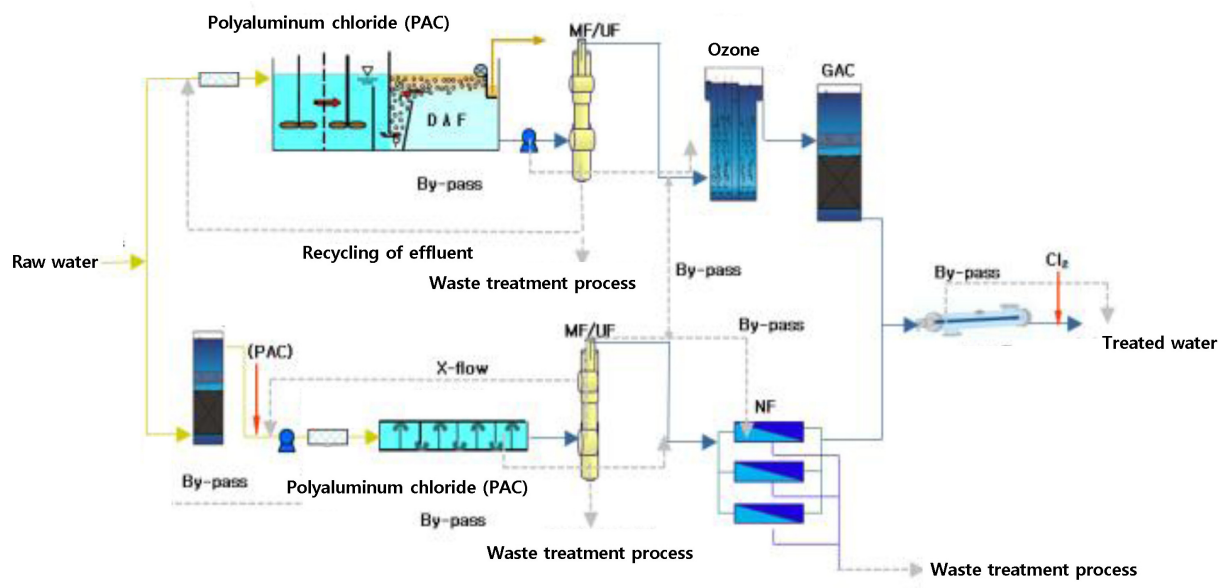

Fig. 1. A schematic flow diagram of the target water treatment system.

Table 1. Specification of water treatment system process

\begin{tabular}{lc}
\hline \multicolumn{1}{c}{ Specification of items } & Value of data \\
\hline Standard $\left(\mathrm{m}^{2}\right)$ & 0.373 \\
Filtration efficiency & Constant rate filtration \\
Bed height $(\mathrm{m})$ & 0.653 \\
Pre-treatment & Ozone \\
Dose $(\mathrm{mg} / \mathrm{L}) /$ Time $(\mathrm{min})$ & $3 / 15.0$ \\
Empty bed contact time $(\mathrm{m} / \mathrm{h})$ & 14 \\
Back washing velocity $(\mathrm{m} / \mathrm{min})$ & Slow backwash: 0.3 \\
& Rinse: 0.69 \\
Operating period & One and a half years \\
\hline
\end{tabular}

Table 2. The physical characteristics of GACs used in this study

\begin{tabular}{cc}
\hline Specification of items & Value of data \\
\hline BET surface area $\left(\mathrm{m}^{2} / \mathrm{g}\right)$ & 930.49 \\
Micro-pore area $\left(\mathrm{m}^{2} / \mathrm{g}\right)$ & 676.01 \\
Pore volume $\left(\mathrm{cm}^{2} / \mathrm{g}\right)$ & 0.571 \\
Micro-pore volume $\left(\mathrm{cm}^{2} / \mathrm{g}\right)$ & 0.31 \\
\hline
\end{tabular}

$0.45 \mu \mathrm{m}$ 막 필터를 이용하여 거른 후 LB agar plate (Difco Laboratories, Detroit, MI, USA)에 $37^{\circ} \mathrm{C}$ 에서 48시간 배양하여 박 테리아 검출 여부를 확인하였다. 박테리아 생체량을 측정하기 위해 서 물 시료 $100 \mu \mathrm{L}$ 를 $\mathrm{LB}$ agar plate에 spreading한 후 $37^{\circ} \mathrm{C}$ 에서 48시간 배양하였다. 박테리아 생체량 측정은 평판계수법을 실시하 였다. 박테리아의 동정은 R2A 배지에 형성된 집락의 형태학적 특 징을 통해 서로 다른 집락 및 색상을 조사하였으며, 확인된 집락을 Reasoner's 2A agar (R2A, Difco Laboratories) 배지에 획선 도말 하여 단일 집락을 분리하였다.

\section{Genomic DNA 추출 및 $16 \mathrm{~S}$ rRNA gene염기서열 분석}

활성탄 역세척 후 탈리된 박테리아를 동정하기 위해 다음과 같 이 실험하였다. DNA 추출은 5\% Chelex 100 (Bio-Rad
Table 3. Characteristics of water quality for source water

\begin{tabular}{lc}
\hline Specification of items & Value of data \\
\hline $\mathrm{pH}$ & 7.42 \\
$\mathrm{DOC}(\mathrm{mg} / \mathrm{L})$ & 4.15 \\
$\mathrm{DOC}$ removal (\%) & 9.28 \\
UV $\left(\mathrm{cm}^{-1}\right)$ & 0.1 \\
Temperature $\left({ }^{\circ} \mathrm{C}\right)$ & $20 \sim 27$ \\
\hline
\end{tabular}

Laboratories, Hercules, CA, USA)을 이용하여 boiling method로 수행하였다. 시료에서 분리한 genomic DNA를 universal PCR primer (forward : AGA GTT TGA TCC TGG CTC AG, reverse : GGT TAC CTT GTT ACG ACT)를 이용하여 세균의 $16 \mathrm{~S}$ ribosomal RNA gene (16S rRNA gene)을 증폭시키기 위해 Gene Amp PCR System 2700 (Applied Bio-systems, Foster-city, CA, USA)으로 polymerase chain reaction (PCR)을 수행하였다. PCR 조건은 $94^{\circ} \mathrm{C}$ 에서 5 분간 반응한 후, $94^{\circ} \mathrm{C}$ 에서 30 초, $55^{\circ} \mathrm{C}$ 에서 45 초, $72^{\circ} \mathrm{C}$ 에서 1 분 30 초의 반응주기를 25 주기 시행하고 $72^{\circ} \mathrm{C}$ 에서 7 분간 반응한다. 증폭산물은 $1 \mathrm{~Kb}$ Plus molecular size marker (Doctor protein, Seoul, Korea)와 함께 1.0\% tris-borate EDTA (TBE) agarose gel에 전기영동을 한 후, ethidium bromide (Et-Br)로 염색하여 Gel-doc XR System (Bio-Rad Laboratories, Hercules, CA, USA)로 크기가 1.5 kilo base pair (Kb)임을 확인하 였다. 크기가 $1.5 \mathrm{~Kb}$ 인 증폭산물은 LaboPass ${ }^{\mathrm{TM}} \mathrm{PCR}$ purification kit (Cosmo, Seoul, Korea)를 이용하여 정제하고, 정제된 산물의 염기서열 확인을 위해 외부기관(Genotech, Daejeon, Korea)에 의뢰하여 염기서열 분석을 수행하였으며, 염기서열들은 National Center for Biotechnology Information (NCBI)의 blast search 를 이용하여 Gene Bank database와 비교•분석하였다. 


\section{4. 통계 분석}

$p$-value는 Student's $t$-test를 이용하여 계산하였다. 통계치는 평균값(mean)과 평균값의 표준 오차(standard error of the mean, $\mathrm{SEM}$ 로 나타내었다. 모든 실험 결과는 세 개의 반복적이고 독립적인 실험을 수행한 결과이고, 그 중 한 결과를 대표적으로 나 타내었다.

\section{결 과}

\section{1. 막공정 및 활성탄 공정에 따른 박테리아 검출}

$\mathrm{G}$ 정수장에 설치된 모형플랜트의 정수처리 과정은 다음과 같다 (Fig. 1). 먼저 막공정을 통해 박테리아를 포함한 입자성 물질이 제 거가 된 후, 입상활성탄 공정을 통하여 맛 - 냄새 물질, TOC 및 $\mathrm{DOC}$ 등을 제거하게 된다. 이때 입상활성탄은 수처리 공정이 지속 됨에 따라 일부 박테리아가 활성탄 내 세공(pore)에 증식하면서 생 물막(biofilm)을 형성하며 생물활성탄으로 전환된다[16-18]. 본 실험에서는 전환된 생물활성탄 내 박테리아의 수처리 공정 가동 시 탈리 여부를 확인하였다. $\mathrm{G}$ 정수장에 설치된 모형플랜트에서 막공 정 및 활성탄 공정에 따른 박테리아 검출 여부를 확인하기 위하여 막공정 유입수 및 막공정 처리수, 그리고 활성탄 공정 처리수 시료 를 실험에 이용하였다. 실험을 진행한 결과, 막공정 유입수에서는 다량의 박테리아가 검출되는 것을 확인할 수 있었다. 그러나 막공 정을 거치고 난 막공정 처리수에서는 박테리아가 증식하지 않았다 (Fig. 2A and B). 따라서 본 모형플랜트에 적용된 막공정을 통하여 박테리아가 효율적으로 제거됨을 알 수 있었다. 그러나 막공정 처 리수가 활성탄 공정을 거치고 나면 다시 박테리아가 나타나는 것을 확인 할 수 있었다(Fig. 2C). 막공정 처리수에서는 나타나지 않던 박 테리아가 활성탄 공정을 거치면서 나타난 것으로 보아 활성탄 처리

(A)

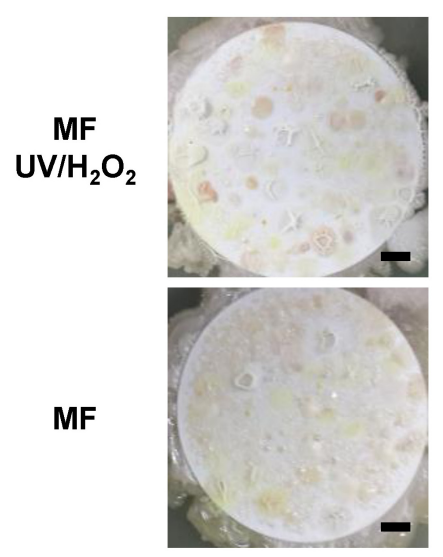

(B)

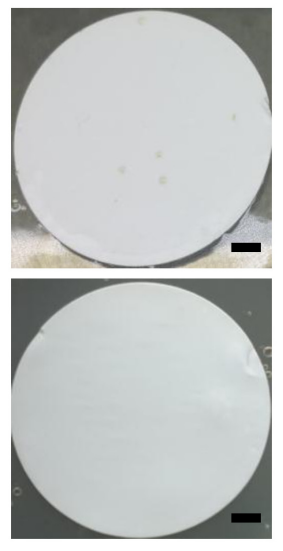

수에서 나타난 박테리아는 생물활성탄에서 탈리되어 나온 것으로 여겨진다. 따라서 고도정수처리공정에서 입상활성탄 또는 생물활 성탄 공정이 막공정 후단에 배치되는 경우에는 반드시 활성탄에서 탈리되어 나온 박테리아를 제어하기 위한 추가적 공정이 필요함을 본 실험을 통하여 확인할 수 있었다.

\section{2. 활성탄 역세척 과정에 따른 박테리아 탈리량 분석}

활성탄의 역세척 가동 전과 역세척 가동 후의 박테리아 탈리량 을 분석한 결과 역세척 전에는 $100 \mu \mathrm{L}$ 시료수 시료 당 약 $5 \mathrm{CFU}$ 정 도의 박테리아가 검출 되는 것을 확인하였다. 그러나 역세척 과정 후에는 활성탄 공정수에서 약 $150 \mathrm{CFU}$ 정도의 박테리아가 검출이 되었다. 역세척 전과 역세척 후의 활성탄 공정수 내 박테리아 량을 비교하였을 때 약 30 배 정도 박테리아 량이 증가하는 것을 확인할 수 있었다(Fig. 3). 따라서 활성탄 공정에서 역세척을 시행하게 되 면 활성탄 내 박테리아의 탈리량이 증가함을 알 수 있었다.

\section{3. 활성탄 역세척 후 탈리된 박테리아 군집 확인}

활성탄 역세척 과정에서 탈리되어 배출되는 박테리아 군집 분포 를 확인하였다. 활성탄 공정 유입수로 정밀여과막 단독 공정 처리

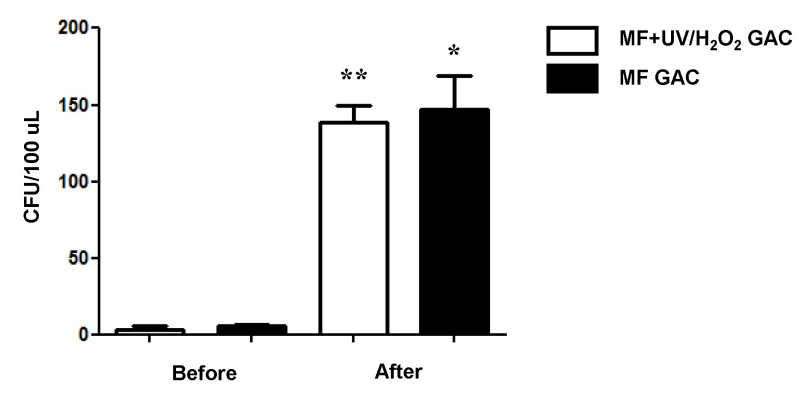

Fig. 3. Bacterial counts of measured before/after backwashing of GAC.

(C)

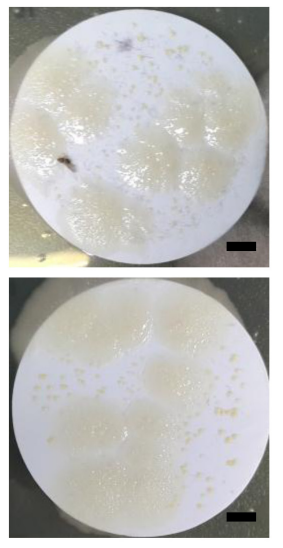

Fig. 2. Observation of microorganisms according to microfiltration water treatment processes (scale bars, 0.5 $\mathrm{cm})$. (A) Before treatment of MF (B) After treatment of MF (C) After treatment of GAC. 
Table 4. Distribution of microorganisms isolated from backwashing of GAC

\begin{tabular}{ccc}
\hline & MF & $\mathrm{MF}+\mathrm{UV} / \mathrm{H}_{2} \mathrm{O}_{2}$ \\
\hline 1 & $\beta$-proteobacterium species & $\beta$-proteobacterium species \\
2 & Porphyrobacter donghaensis & Porphyrobacter donghaensis \\
3 & Polaromonas rhizophaerae & Polaromonas rhizophaerae \\
4 & Hydrogenophaga species & - \\
5 & Pseudonocardia species & - \\
\hline
\end{tabular}

수를 이용하여 분석한 결과, $\beta$-proteobacterium species, Porphyrobacter donghaensis, Polaromonas rhizophaerae, Hydrogenophaga species, Pseu-donocardia species 등 총 5종 의 우점종 박테리아가 나타나는 것을 확인할 수 있었다(Table 4). 그러나 정밀여과막 공정 이후 UV 공정을 추가 처리한 공정 처리수 를 활성탄 공정에 유입한 경우 $\beta$-proteobacterium species, Porphyrobacter donghaensis, Polaromonas rhizophaerae 등 총 3종의 우점종 박테리아만 나타나고, Hydrogenophaga species 와 Pseudocardia species 2 종의 박테리아는 나타나지 않는 것을 확인할 수 있었다. UV 공정 처리수에서 나타나지 않는 2 종의 박테 리아는UV에 대한 감수성이 다른 종에 비해 높아 더 이상 증식을 하 지 않는 것으로 보인다.

\section{고 찰}

최근 생활수준의 향상과 소비자의 물에 대한 안전 요구도 급증 등 다양한 요인들에 의해 수질 환경에 대한 관심이 증대되고 있다. 또한 급속한 산업화와 이로 인한 기후 변화로 인해 변화 되는 수질 에 대한 안전성에 대한 연구 및 기존 정수처리시설 노후화에 따른 정수 시설 개량 및 정수 처리 시설의 증설에 대한 필요성이 커지고 있다. 본 연구에서는 $\mathrm{G}$ 정수장 내의 모형플랜트에서 사용된 원수 및 각 공정에 대한 공정수를 물 시료로 채취하여 정밀여과막 공정 및 입상활성탄 공정에서 박테리아의 거동에 대해 확인을 하였으며, 또 한 입상활성탄의 지속적 사용을 위한 역세척 가동 시 박테리아의 탈리 여부를 확인하였다. 그리고 마지막으로 탈리된 박테리아의 종 동정을 위해 $16 \mathrm{~S}$ rRNA gene을 이용한 종 동정을 실시하였다.

첫 번째로 본 연구에서는 공정 별 박테리아의 거동을 확인하였 다. 그 결과 정밀막여과 공정을 거치는 경우 수계 내 존재하는 박테 리아가 제거가 되는 것을 확인하였다. 기존의 정수처리 공정은 주 로 탁도 물질 및 부유물질의 제거 및 소독이 주 목적이었다. 그러나 빈번한 유해물질의 출현으로 고도정수처리 기술이 도입되기 시작 하였고, 그 중 하나가 본 연구에서 적용된 정밀막여과 공정이다. 이 미 많은 연구에서 정밀막여과를 이용한 막분리(membrane separation) 기술에 대한 효용성은 입증이 되어왔다[19,20]. 본 연 구에서 사용한 정밀여과막과 유사한 여과막을 사용한 연구에서 병 원성 박테리아를 포함하는 수인성 장 - 관계 바이러스가 제거되는 것을 확인하였다. 그러나 실제 플랜트 공정 도입 시 박테리아가 제 거되는 것을 확인 한 것은 이번이 처음이다. 따라서 정밀막여과 공 정이 실 공정에 도입된 상태에서도 효과적으로 박테리아를 제거하 는 것을 본 실험을 통해서 알 수 있었다.

그러나. 정밀여과막 공정수가 다시 입상활성탄 공정을 거치는 경우 다시 물 시료에서 박테리아가 검출이 되기 시작하였다. 이것 은 정밀막여과 공정 후단에 입상활성탄 공정이 배치되는 경우에는 제거된 박테리아와는 다르게 입상활성탄 내 흡착된 박테리아 일부 가 탈리한 것으로 보인다. 실제로, 다른 타 연구에서도 이와 유사한 현상이 나타나는 것을 확인 할 수 있다. 입상활성탄에 형성되어 있 는 생물막에 존재하는 박테리아는 공정이 지속됨에 따라 입상활성 탄 공정에서 탈리되어 처리수 내에 지속적으로 존재하게 된다. 물 론, 이때 생물막 내 형성된 박테리아의 경우 생물학적 활성도를 가 지며 특정 효소를 분비하거나 대사작용을 가지면서 수계 내 유기 오염물질을 제거하는 특성을 지닌다[8,21-23]. 그러나 입상활성 탄 공정 처리수에 박테리아가 지속적으로 존재하는 경우, 후단 공 정에 영향을 미칠 뿐 아니라 이에 따른 생물학적 대사에 의한 부산 물로 인해 여러 가지 영향을 미칠 수도 있다. 따라서 정밀막여과 공 정 처리 후 입상활성탄 공정을 거치게 되는 경우 다음 후단 공정에 영향을 미치지 않도록, 탈리되어 나타나는 박테리아를 제어할 만한 추가적 공정이 필요함을 알 수가 있다.

두 번째로 입상활성탄 공정 가동 시 역세척에 따른 박테리아 탈 리량의 변화를 확인하였다. 그 결과, 역세척 전에 비해 역세척 후 박 테리아 탈리량이 약 30 배 정도 증가하는 것을 확인 할 수 있었다. 실 제, 타 연구에서 역세척에 따른 영향을 평가한 결과를 살펴보면, 역 세척으로 인해 입상활성탄 표면에 상주하던 박테리아의 약 43\%가 탈리되어 처리수로 유출됨을 알 수 있다[15]. 입상활성탄에서 역세 척 시 박테리아의 탈리량이 증가하는 것은 크게 두 가지 측면에서 살펴볼 수 있다. 먼저 생물활성탄 공정 측면에서, 입상활성탄 내 박 테리아 탈리량의 증가는 박테리아의 오염물질 제거능의 감소를 뜻 한다. 실제로 타 연구에서 역세척 가동 후 일시적으로 입상활성탄 의 오염물질 제거능이 감소하였고, 이것이 박테리아의 감소로 인한 것임을 밝힌 바 있다[15]. 따라서 본 연구와 종합적으로 살펴봤을 때 입상활성탄의 생물활성탄적 효과를 지속하기 위해서는 반드시 역세척 공정의 시기와 강도에 대해 고려를 해야 할 것이다. 두 번째 로는 입상활성탄 공정 처리수에서 일시적인 박테리아 탈리량의 증 가가 후단 공정에 영향을 미칠 수 있다는 점이다. 이것은 앞서 본 바 와 유사하게 입상활성탄 공정에서 탈리되어 나오는 박테리아를 제 
어하기 위한 별도의 공정이 반드시 필요함을 알 수 있다.

마지막으로, 본 연구에서는 역세척 과정에서 탈리되어 나오는 박테리아의 종을 분석하였다. 그 결과 역세척 과정에서 탈리되어 나타나는 5 종의 우점종 박테리아는 타 연구와 마찬가지로 수계 내 의 특성에 따라 달라지므로 큰 의미를 나타내진 않았다[24]. 한가지 흥미로운 것은 정밀여과막 단독 공정을 거친 처리수가 유입되었을 때에는 5종의 우점종 박테리아( $\beta$-proteobacterium species, Porphyrobacter donghaensis, Polaromonas rhizophaerae, Hydrogenophaga species, Pseudonocardia species)가 나타났 으나, 정밀여과막 후단에 UV 공정이 추가가 된 경우, 5 종의 우점종 박테리아 중 Hydrogenophaga species와 Pseudonocardia species 등 2종의 우점종 박테리아는 나타나지 않는다는 점이다. 이것은 아마도 2종의 우점종 박테리아는 UV에 대한 민감도가 타 우점종 박테리아에 비해 높기 때문인 것으로 여겨진다. 따라서 입 상활성탄 공정에서 생물활성탄 형성에 의한 이점을 살리기 위해서 는 UV 공정의 사용여부 및 배치 여부를 반드시 고민해야 할 것으로 보인다. 또한 생물활성탄 공정 이용 시 활성탄 내 박테리아 선별 시 $\mathrm{UV}$ 에 대한 민감도 차이도 고려해야 할 것이다.

본 연구에서는 국내 $\mathrm{G}$ 정수장 내 설치된 파일럿연구시설을 이용 하여 고도정수처리시설 내 정밀여과막 공정 및 입상활성탄 공정에 서 박테리아의 거동을 확인 함으로서 수처리 공정의 설계에 유용한 지표를 제공하고자 하였다. 역세척 가동 여부에 따른 활성탄 공정 수 내 박테리아 탈리량의 변화는 입상활성탄 및 생물활성탄 공정에 있어 역세척 가동 시기 및 강도에 있어 중요한 단서를 제공하였다. 또한 정밀여과막 공정 이후에 UV 공정을 추가하여 운행한 경우 입 상활성탄 내 박테리아 우점종이 변화하는 것을 확인 함으로서, 생 물활성탄 공정에 의한 오염물질 제거에서 박테리아 군집의 UV에 대한 민감도가 고려되어야 함을 알 수 있었다.

\section{요 약}

경제성장으로 생활수준이 향상됨에 따라 국민건강을 직접적으 로 위협하는 수질오염에 대해 세계적으로 관심을 갖게 되었으며, 최근 맛 - 냄새 유발물질 발생의 문제가 대두되기 시작했다. 본 연 구에서는 $\mathrm{G}$ 정수장 내의 모형플랜트에서 사용된 원수 및 각 공정에 대한 공정수를 물 시료로 채취하여 정밀여과막 공정 및 입상활성탄 공정에서 박테리아의 거동에 대해 확인하였고, 또한 입상활성탄의 지속적 사용을 위한 역세척 가동 시 박테리아의 탈리 여부와 종 동 정을 실시하였다. 분석 결과, 정밀막여과 공정을 거치는 경우 수계 내 존재하는 박테리아가 제거가 되는 것을 확인하였으며, 역세척 가동시 $\beta$-proteobacterium species, Porphyrobacter dong- haensis, Polaromonas rhizophaerae, Hydrogenophaga species, Pseudonocardia species 등 총 5종의 우점종 박테리아가 나타나 는 것을 확인할 수 있었으며, 정밀여과막 공정 이후 UV 공정을 추가 처리한 공정 처리수를 활성탄 공정에 유입한 2종의 박테리아는 나 타나지 않는 것을 확인함에 따라 생물활성탄 공정에 의한 오염물질 제거에서 박테리아 군집의 UV에 대한 민감도가 고려되어야 함을 알 수 있었다. 이를 바탕으로 수처리 공정의 설계에 유용한 지표를 제공하고자 하였다.

Acknowledgements: 본 연구는 환경부의 "The Eco-Innovation project (Global Top project)" 연구비 지원에 의해 수행 되었습니 다(GT-SWS-11-01-006-0).

Funding: None

Conflict of interest: None

\section{References}

1. Ho L, Hoefel D, Bock F, Saint CP, Newcombe G. Biodegradation rates of 2-methylisoboneol and geosmin through sand filters and in bioreactors. Chemosphere. 2007;66(11):2210-2218.

2. Vorosmarty CJ, McLntyre PB, Gessner MO, Dudgeon D, Prusevich A, Green P, et al. Global threats to human water security and river biodiversity. Nature. 2007;467(7314):555-561.

3. Robertson RF, Hammond A, Jauncey K, Beveridge MCM, Lawton LA. An investigation into the occurrence of geosmin responsible for earthy-musty taints in UK farmed rainbow trout, Onchorhynchus mykiss. Aquacul-ture. 2006;259(8):153-163.

4. Gerber NN, Lechevalier HA. Geosmin, an Earthy-smelling substance isolated from Actinomycetes. Appl En-viron Microbiol. 1965;13(6):935-938.

5. Madaeni SS, Fane AG, Grohmann GS. Virus removal from water and wastewater using membrane. J Mem-brane Sci. 1995; 102(1):65-75.

6. Taedosiu CC, Kennedy MD, Straten HA, Schippers JC. Evaluation of secondary refinery effluent treatment using ultrafiltration membranes. Water Res. 1999:33(9):2172-2180.

7. Asami M, Aizawa T, Morioka T, Nishijima W, Tabata A, Magara Y. Bromate removal during transition from new granular activated carbon (GAC) to biological activated carbon (BAC). Water Res. 1999:33(12):2797-2804.

8. Scholz M, Martin RJ. Ecological equilibrium on biological activated carbon. Water Res. 1997;31(12):2959-2968.

9. Walter WJ, Pirbazari M, Melson GL. Biological growth on activated carbon: an investigated by scanning electronic ROS copy. Environ Sci Technol. 1978;12(7):817-819.

10. Moll DM, Summers RS, Fonseca AC, Matheis W. Impact of temperature on drinking water biofilter perfor-mance and microbial community structure. Environ Sci Technol. 1999;33(14): 2377-2382.

11. Lanmark J, Storey MV, Ashbolt NJ, Stenstrom TA. Artificial 
groundwater treatment: biofilm activity and organic carbon removal performance. Water Res. 2004;38(3):740-748.

12. Chestnutt TE, Bach MT, Mazyck DW. Improvement of thermal reactivation of activated carbon for the removal of 2-emthylisoborneol. Water Res. 2007;41(1):79-86.

13. Dussert B, Van Stone G. The biological activated carbon process for water purification. Water Eng Manage. 1994;141(21):22-24.

14. Sevais P, Billen G, Bouillot P, Benezet M. A pilot study of biological GAC filtration in drinking water treat-ment. J Wat Sup. 1992;41(3):163-168.

15. Park S, Lee S, Sin S, Jun C, Kim C. Variation of pollutant removal efficiency and backwashing effect of BAC basin in advanced water treatment processes. J Kor Soc Environ Eng. 2008; 30(1):45-53.

16. Carlson KH, Amy GL. Ozone and biofiltration optimization for multiple objective. J AWWA. 2001;93(1):88-98.

17. Park J, Takizawa S, Katayama H, Ohgaki S. Biofilter pretreatment for the control of microfiltration mem-brane fouling.Water Sci Tech: Water Supply. 2002; 2(2):193-199.

18. Son HJ, Park HK, Lee SA, Jung EY, Jung CW. The characteristics of microbial community for biological activated carbon in water treatment plant. J Kor Soc Environ Eng. 2005;27(11):1311-
1320.

19. Taedosiu CC, Kennedy MD, Straten HA, Schippers JC. Evaluation of secondary refinery effluent treatment using ultra filtration membranes. Water Res. 1999;33(9):2172-2180.

20. Cho J, Lim J, Baek D, Lee SH, Lee IS, Lee H, et al. Development of techniques for evaluating the virus re-moval rate using adenovirus. J Korean Soc Water \& Wastewater. 2015;29(6): 633-641.

21. Klimenko N, Winter-Nielsen M, Smolin S, Nevynna L, Sydorenko J. Role of the physicochemical factors in the purification process of water from surface-active matter by biosorption. Water Res. 1992;36(20):231-241.

22. Ridgway HF, Olsan BH. Scanning electron microscope evidence for bacterial colonization of drinking water distribution system. Appl Environ Microbiol. 1981;21(3):274-287.

23. Son HJ, Yoo SJ, Roh JS, Yoo PJ. Biological activated carbon (BAC) process in water treatment. J Kor Soc Environ Eng. 2009; 31(4):308-322.

24. Baek D, Lim J, Cho Y, Ahn YT, Lee H, Park D, et al. Investigation of geosmin removal efficiency by micro-organism isolated from biological activated carbon. J Korean Soc Water \& Wastewater. 2015;29(1):47-55. 